Zeszyty Naukowe Szkoły Głównej Gospodarstwa Wiejskiego

Ekonomika i Organizacja Gospodarki Żywnościowej nr 115, 2016: 71-89

Leonard Smolarski

Agencja Restrukturyzacji i Modernizacji Rolnictwa

Śląski Oddział Regionalny w Częstochowie

\title{
Wielkość dopłat bezpośrednich a produkcja, koszty i dochodowość działalności w indywidualnych gospodarstwach rolnych
}

\section{Wstęp}

Kwestia dochodów uzyskiwanych przez właścicieli rodzinnych gospodarstw rolniczych wciąż jest zagadnieniem pozostającym w sferze analiz i badań w teorii ekonomii, a szczególnie ekonomistów rolnych. Zegar [2008, s. 9-35] stwierdza, że kwestia dochodów w rolnictwie polega na znacząco gorszej sytuacji ekonomicznej oraz ogółu warunków życia ludności rolniczej w stosunku do ludności nierolniczej. Została ona wydobyta na światło dzienne na pewnym etapie historycznego rozwoju, tj. wraz z industrializacją. Utrzymująca się w rolnictwie stała deprecjacja dochodów wynika z naturalnych i ekonomicznych uwarunkowań alokacji czynników produkcji - nieefektywnej według kryterium Pareto. Mechanizm kreacji dochodów rolników w tych warunkach nie kieruje się jedną z podstawowych zasad ekonomii klasycznej, tj. zasadą przyrostów krańcowych, według której jednostki ekonomiczne dokonują alokacji swoich zasobów produkcji do najbardziej efektywnych ich zastosowań. Alokacja taka w przypadku gospodarstw indywidualnych jest ograniczona różnymi czynnikami, a głównie przez małą elastyczność popytu na żywność oraz małą mobilność i niepodzielność czynników produkcji rolniczej. Ponadto deprecjacja rolnictwa przez mechanizm rynkowy ma charakter uniwersalny w ramach gospodarki rynkowej, gdyż mechanizm ten ustala cenę dla konkretnych warunków podaży i popytu, które mogą nie odzwierciedlać faktycznie wytworzonej wartości dodanej, lecz przesądzają o wartości zrealizowanej, czyli o dochodzie. W związku z tym w rolnictwie występuje zjawisko tzw. ucieczki (drenażu) nadwyżki ekonomicznej do innych sektorów gospodarki [Woś 2000, s. 34, Kowalski i Rembisz 2005, s. 7-63, Czyżewski 2007, s. 19-21, Kowalski 2013, s. 71-81, Rembisz i Bezat- 
-Jarzębowska 2013, s. 9-105]. A zatem interwencjonizm w rolnictwie koryguje zawodność mechanizmu rynkowego, gdyż część nadwyżki ekonomicznej, która w warunkach rynkowych odpływa do pozarolniczych sektorów, wraca z powrotem do rolnictwa. Wsparcie finansowe nie powinno jednak zakłócać funkcjonowania mechanizmu rynkowego, gdyż właściwe sygnały cenowe, zarówno produktów, jak i czynników produkcji, kształtowane są na rynku. Interwencyjne oddziaływanie na ich ceny może zniekształcać ich informacyjną funkcję. Wsparcie finansowe gospodarstw rolniczych w ramach wspólnej polityki rolnej (WPR) w postaci dopłat bezpośrednich ma charakter transferów od podatnika bezpośrednio do producenta rolnego, przez co zmniejsza prawdopodobieństwo wysyłania mylnych sygnałów z rynku do właścicieli gospodarstw rolnych. Wprowadzając system dopłat bezpośrednich, uwzględniono oczekiwania konsumentów i podatników, dając jednocześnie rolnikom swobodę wyboru kierunków produkcji, uwzględniając wymagania rynkowe. Ustalono, że większość dotacji będzie wypłacana rolnikom niezależnie od wielkości bieżącej produkcji ${ }^{1}$.

Dopłaty bezpośrednie w krajach Unii Europejskiej (UE) zostały wprowadzone w ramach reformy Mac Sharry'ego w 1992 roku, jako instrument wspierania dochodów producentów rolnych [The development... 1991, s. 1-20, Keeney i in. 1997, s. 1-12]. W latach 2004-2014 w Polsce obowiązywał uproszczony system płatności, tzw. system jednolitej płatności obszarowej SAPS (ang. single area payment scheme), który polegał na stosowaniu płatności do 1 ha UR, bez względu na rodzaj produkcji rolniczej [Ustawa z 18 grudnia 2003 r., Ustawa z 26 stycznia 2007 r., Ustawa o zmianie...]. W latach 2004-2013 w ramach dopłat bezpośrednich polscy rolnicy otrzymali około 93 mld zł. W UE z dopłat bezpośrednich pochodzi prawie połowa dochodów rolników. Jest to zatem bardzo istotny element opłacalności produkcji rolnej. Wsparcie polskiego rolnictwa, za pośrednictwem dopłat bezpośrednich, wpływa nie tylko na wzrost wartości produkcji, ale przede wszystkim na dochody polskich gospodarstw rolnych ${ }^{2}$ [Szpo-

\footnotetext{
${ }^{1}$ Jednym z głównych impulsów do wprowadzenia oraz późniejszych modyfikacji form płatności bezpośrednich były uzgodnienia dotyczące międzynarodowego handlu artykułami w ramach WTO (World Trade Organisation - Światowa Organizacja Handlu). Komisja Europejska dążyła do takiego przekształcenia płatności bezpośrednich, aby można je było zaliczyć do subwencji, które nie zakłócają funkcjonowania rynku (tzw. green box), przez co stałyby się one wolne od wszelkich restrykcji ilościowych wynikających z porozumień WTO [Judzińska i Łopaciuk 2011, s. 9-10].

${ }^{2}$ Realizacja koncepcji zrównoważonego rozwoju rolnictwa może oznaczać, że w niektórych gospodarstwach obniży się (lub też ulegnie ograniczeniu) poziom nakładów pochodzenia przemysłowego. Nastapi więc pogorszenie wyników produkcyjnych i ekonomicznych, w konsekwencji czego zmniejszą się dochody rolników, ograniczając w ten sposób możliwości akumulacji i rozwoju ich gospodarstw, stąd zachodzi potrzeba wspierania zarówno relatywnie niższego poziomu dochodów rolniczych, jak i dalszego rozwoju rolnictwa. Strategia taka jest zgodna z koncepcją zrównoważonego rozwoju zarówno pod względem ekonomicznym, środowiskowym, jak i społecznym [Komorowska 2014, s. 98-110].
} 
janowska 2006, s. 332-336, Kutkowska 2009, s. 101-109, Marcysiak i Marcysiak 2010, s. 253-256]. Celem płatności bezpośrednich jest zabezpieczenie odpowiedniego poziomu dochodów rolników, bez wpływu na wzrost cen dla konsumentów. W swych decyzjach rolnicy mogą się więc kierować sygnałami rynkowymi, co jest niezwykle ważne w sytuacji dostosowania produkcji do warunków jednolitego rynku [Berkum i Turner 2010, s. 4-16, Davidova 2011, s. 107-120, Żmija 2011, s. 193-201].

Na wartość produkcji ogółem uzyskanej w ramach działalności operacyjnej gospodarstwa rolnego składa się produkcja roślinna i zwierzęca oraz pozostała. Jak podaje Klepacki [1997, s. 74], typowe gospodarstwa rolnicze zajmują się produkcją roślinną i zwierzęcą. Przetwórstwo czy świadczenie usług występuje w nich rzadko.

$\mathrm{Na}$ wartość kosztów produkcji ogółem składają się środki produkcji wraz ze świadczeniami finansowymi mającymi związek z działalnością operacyjną gospodarstwa rolnego.

Zgodnie z przyjętą metodyką FADN pierwszą nadwyżką ekonomiczną jest wartość dodana brutto gospodarstwa rolnego. Jest ona obliczana poprzez odjęcie zużycia pośredniego od produkcji ogółem i dodanie salda dopłat i podatków dotyczących działalności operacyjnej. Dopłaty zwiększają wartość dodaną brutto, a podatki powodują jej zmniejszenie. Jest to kategoria ekonomiczna, która odzwierciedla nowo wytworzoną wartość $\mathrm{w}$ gospodarstwie rolnym w okresie obrachunkowym przez czynniki wytwórcze (tj. ziemię, pracę i kapitał) niezależnie od tego, kto jest ich właścicielem, a także uwidacznia wpływ polityki państwa na pozycję ekonomiczną gospodarstwa rolnego, kształtowaną przez system dopłat (w tym dopłat obszarowych) i podatków.

Dochód z rodzinnego gospodarstwa rolnego jest podstawową nadwyżką ekonomiczną uzyskiwaną $\mathrm{w}$ ramach działalności operacyjnej gospodarstwa ${ }^{3}$. Dochód ten stanowi opłatę za własne czynniki wytwórcze (praca, ziemia i kapitał) zaangażowane do działalności operacyjnej gospodarstwa rolnego oraz ryzyko podejmowane przez prowadzącego gospodarstwo w roku obrachunkowym ${ }^{4}$.

\footnotetext{
${ }^{3}$ Dochód $\mathrm{z}$ rodzinnego gospodarstwa rolniczego obliczony został zgodnie z metodyką FADN, w której od wartości dodanej brutto odejmuje się amortyzację i uzyskuje się wartość dodaną netto, od której następnie odejmuje się koszty czynników zewnętrznych, a dodaje się saldo dopłat i podatku VAT dotyczących inwestycji.

${ }^{4}$ Obliczony dochód z rodzinnego gospodarstwa rolnego kończy rachunek ekonomiczny w gospodarstwie rolnym według metody FADN. W tej metodzie przedmiotem zainteresowania są wyniki ekonomiczne osiągane przez gospodarstwo rolne jako całość. Na dochód wypracowany przez rodzinne gospodarstwo rolne, poza produkcją typowo rolniczą, składają się m.in. otrzymane przez to gospodarstwo dotacje do produkcji rolniczej, zarobkowanie maszynami i narzędziami gospodarstwa, działalność agroturystyczna. W metodzie FADN nie bada się dochodów rodziny rolniczej, a zatem dochody uzyskane przez rodzinę rolniczą poza gospodarstwem rolnym niezwiązane
} 


\section{Cel i metody badań}

Celem badań było określenie zmian w wielkości produkcji i kosztów w indywidualnych gospodarstwach rolnych w zależności od poziomu dopłat bezpośrednich. Dobór gospodarstw do badań był celowy. Badaniami objęto indywidualne gospodarstwa rolnicze $\mathrm{z}$ terenu województwa śląskiego, uczestniczące w systemie FADN (Farm Accountancy Data Network) - europejskim systemie zbierania danych z gospodarstw rolnych, prowadzące rachunkowość rolną pod nadzorem Instytutu Ekonomiki Rolnictwa i Gospodarki Żywnościowej-Państwowy Instytut Badawczy (IERiGŻ-PIB) [Ustawa z 29 listopada $2000 \mathrm{r}$.]. Obiekty znajdujące się w polu obserwacji Polskiego FADN są to gospodarstwa towarowe mające zasadniczy udział w tworzeniu wartości dodanej rolnictwa. Za takie uznaje się te, które mieszczą się w grupie gospodarstw wytwarzających w danym regionie FADN około 90\% wartości standardowej nadwyżki bezpośredniej. Ustalona liczebność próby Polskiego FADN, zaakceptowana przez Komisję Europejska, liczyła 11191 gospodarstw reprezentujących obszar całego kraju. W tej liczbie znalazło się 1426 gospodarstw z Regionu 800 - Małopolska i Pogórze, w którym klasyfikowało się 301 badanych gospodarstw z terenu województwa śląskiego. Był to więc dobór celowy, odzwierciedlający liczebność przy uwzględnieniu struktury typów rolniczych, wielkości ekonomicznej i powierzchni użytków rolnych (UR).

W opracowaniu analizie poddano indywidualne gospodarstwa rolne $\mathrm{z}$ województwa śląskiego, prowadzące rachunkowość rolną w latach 2005-2008. Obszar ten został wybrany z uwagi na specyficzny charakter w ujęciu makroekonomicznym. W regionie tym gospodarstwa rolnicze położone są wokół terenów silnie uprzemysłowionych, $\mathrm{z}$ największą w kraju aglomeracją górnośląską (o znaczeniu europejskim), a rolnictwo jest tam bardzo zróżnicowane zarówno pod względem wielkości gospodarstw, jak i charakteru produkcji. Wiele gospodarstw znajduje się na terenach miast i gmin miejsko-wiejskich.

Oceny wielkości produkcji i kosztów w badanych gospodarstwach rolnych dokonano na podstawie analizy zmian w wartości i strukturze, jakie zachodziły w poszczególnych latach analizowanego okresu. Przy określeniu zależności między zmianami produkcji i kosztów a poziomem dopłat bezpośrednich gospodarstwa rolnicze podzielono na grupy. Kryterium podziału była wysokość dopłat bezpośrednich do gospodarstwa. Opierając się na liście rankingowej badanych gospodarstw rolnych, wyodrębniono grupy według metody tzw. tercyli. Pierwsza grupa gospodarstw obejmowała 33,3\% ich zbiorowości o najniższym

z funkcjonowaniem gospodarstwa, np. z pracy zawodowej są dochodami prywatnymi, niebędącymi przedmiotem zainteresowania FADN [Jasińska 2008, s. 20-23]. 
poziomie płatności bezpośrednich, druga o przeciętnej (33,3\% zbiorowości), a trzecia o wartości najwyższej (33,3\% zbiorowości). W ten sposób uzyskano podział gospodarstw rolniczych ze względu na poziom płatności bezpośrednich na pierwszą (I), drugą (II) oraz trzecią (III) grupę.

\section{Wyniki badań}

W tabeli 1 przedstawiono strukturę rodzajową wartości produkcji badanych gospodarstw rolnych netto (bez podatku VAT), wytworzoną w danym roku obrachunkowym $\mathrm{w}$ ramach działalności operacyjnej. Podstawą wartości produkcji ogółem $\mathrm{w}$ analizowanym okresie prawie $\mathrm{w}$ całości była produkcja rolnicza (średnio 98,5\% udziału w strukturze), która wykazywała tendencję rosnącą do 179030 zł w 2007 roku (w 2008 r. w porównaniu do 2005 r. produkcja wzrosła o 30,7\%). W niewielkim zakresie rolnicy świadczyli usługi własnym sprzętem na zewnątrz gospodarstwa, za które w 2005 roku otrzymali średnio 1419,5 zł, a w 2006 roku była to kwota jeszcze mniejsza (1086,4 zł), jednakże w kolejnych dwóch latach wystąiła tendencja rosnąca do 2047,7 zł.

Na uwagę zasługuje fakt, że następowało systematyczne powiększanie działalności agroturystycznej przez rolników. Chociaż w ujęciu wartościowym były to kwoty niewielkie (średnio około 90 zł), wskazuje to jednak, że rolnicy poszukują różnych rozwiązań i możliwości zwiększenia swoich dochodów. Przykładem mogą być wielkości pozostałych przychodów z działalności operacyjnej gospodarstwa rolniczego, które w 2005 roku wynosiły 340,2 zł, a w 2008 roku wzrosły do $952,6 \mathrm{zl}$, tj. o $180 \%$. Minimalny był też zakres usług własnych na rzecz inwestycji gospodarstwa rolnego, które obejmują koszt pracy ciagników oraz samochodów ciężarowych i osobowych, który wynosił średnio 225,4 zł. Może to świadczyć o tym, że gospodarstwa te prowadziły nakłady inwestycyjne $\mathrm{w}$ badanym okresie z pomocą dodatkowych środków finansowanych z tytułu różnych form dotacji, lecz nie angażowały do tego własnego sprzętu, gdyż pomoc taka podlegała rozliczeniu fakturowemu. Korzystały one dlatego głównie $\mathrm{z}$ usług obcych $\mathrm{w}$ tym zakresie.

Ogółem średnia wartość całej produkcji gospodarstwa rolniczego wykazywała tendencję rosnąca, jednakże niejednolite było jej tempo. W 2005 roku wynosiła 137933,5 zł i wzrastała średnio około $15 \%$ rocznie do 2007 roku. W 2008 roku osiagnęła wartość 181241,3 zł, czyli w stosunku do 2007 roku wzrosła zaledwie o 37,5 zł. Taka sytuacja może świadczyć o roli płatności bezpośrednich w procesach produkcyjnych gospodarstw. W pierwszych dwóch latach środki finansowe $\mathrm{z}$ dopłat bezpośrednich były $\mathrm{w}$ większości angażowane $\mathrm{w}$ produkcję. W 2007 roku użytkownicy gospodarstw rolnych mogli również przezna- 
czać część pieniędzy na inne cele, niezwiązane z produkcją rolniczą, a ponadto $\mathrm{w}$ tym roku płatności obszarowe były relatywnie mniejsze w stosunku do pozostałych lat, co w sumie przełożyło się na wyhamowanie produkcji w 2008 roku.

Tabela 1

Wartość i struktura produkcji

\begin{tabular}{|c|c|c|c|c|c|c|c|c|c|c|}
\hline \multirow{3}{*}{$\begin{array}{l}\text { Wyszczegól- } \\
\text { nienie }\end{array}$} & \multicolumn{8}{|c|}{ Lata } & \multirow{2}{*}{\multicolumn{2}{|c|}{$\begin{array}{c}\text { Zmiana } \\
2008 / 2005\end{array}$}} \\
\hline & \multicolumn{2}{|c|}{2005} & \multicolumn{2}{|l|}{2006} & \multicolumn{2}{|c|}{2007} & \multicolumn{2}{|l|}{2008} & & \\
\hline & zł & $\%$ & zł & $\%$ & zł & $\%$ & zł & $\%$ & zł & $\%$ \\
\hline \begin{tabular}{|l|} 
Razem \\
produkcja \\
rolnicza \\
\end{tabular} & 135884,8 & 98,6 & 164285,4 & 98,6 & 179030,0 & 98,8 & 177621,9 & 98,0 & 41737,1 & 130,7 \\
\hline $\begin{array}{l}\text { Produkcja } \\
\text { leśna }\end{array}$ & 93,6 & 0,1 & 151,0 & 0,1 & 130,3 & 0,1 & 146,4 & 0,1 & 52,8 & 156,4 \\
\hline $\begin{array}{l}\text { Produkcja } \\
\text { nierolnicza }\end{array}$ & 0,2 & 0,0 & 26,3 & 0,0 & 15,9 & 0,0 & 0,6 & 0,0 & 0,4 & 300,0 \\
\hline \begin{tabular}{|l|} 
Usługi \\
świadczone \\
własnym \\
sprzetem na \\
zewnatrz go- \\
spodarstwa \\
rolnego \\
\end{tabular} & 1419,5 & 1,0 & 1086,4 & 0,7 & 1195,5 & 0,7 & 2047,7 & 1,1 & 628,2 & 144,3 \\
\hline $\begin{array}{l}\text { Usługi agro- } \\
\text { turystyczne }\end{array}$ & 9,5 & 0,0 & 5,9 & 0,0 & 122,8 & 0,1 & 222,4 & 0,1 & 212,9 & 2341,1 \\
\hline \begin{tabular}{|l|} 
Usługi \\
własne na \\
rzecz inwe- \\
stycji gospo- \\
darstwa \\
rolnego \\
\end{tabular} & 167,2 & 0,1 & 381,6 & 0,2 & 189,7 & 0,1 & 163,2 & 0,1 & $-4,0$ & 97,6 \\
\hline $\begin{array}{l}\text { Czynsze } \\
\text { dzierżawne }\end{array}$ & 12,4 & 0,0 & 2,8 & 0,0 & 16,3 & 0,0 & 10,1 & 0,0 & $-2,3$ & 81,5 \\
\hline $\begin{array}{l}\text { Odszko- } \\
\text { dowania } \\
\text { produkcyjne } \\
\text { - wspólne } \\
\end{array}$ & 6,1 & 0,0 & 191,6 & 0,1 & 63,5 & 0,0 & 76,4 & 0,1 & 70,3 & 1252,5 \\
\hline \begin{tabular}{|l|} 
Pozostałe \\
przychody \\
z działalno- \\
ści operacyj- \\
nej gospo- \\
darstwa \\
rolnego \\
\end{tabular} & 340,2 & 0,2 & 541,9 & 0,3 & 439,8 & 0,2 & 952,6 & 0,5 & 612,4 & 280,0 \\
\hline \begin{tabular}{|l|} 
Ogółem \\
wartość pro- \\
dukcji go- \\
spodarstwa \\
rolnego
\end{tabular} & 137933,5 & 100,0 & 166672,9 & 100,0 & 181203,8 & 100,0 & 181241,3 & 100,0 & 43307,8 & 131,4 \\
\hline
\end{tabular}

Źródło: Opracowanie własne na podstawie danych FADN. 
W tabeli 2 przedstawiono wartość i strukturę produkcji według wysokości dopłat bezpośrednich w badanych gospodarstwach. Największe wartości produkcji ogółem uzyskiwały gospodarstwa z grupy o najwyższym poziomie dopłat bezpośrednich. W 2005 roku wynosiła ona średnio 230,4 tys. zł i systematycznie wzrastała do 2007 roku (288 tys. zł), nieznacznie spadając w 2008 roku. Jeszcze większa zmiana w przyroście wartości produkcji w tym samym okresie nastapiła w gospodarstwach o średnim poziomie dopłat, jednakże nie stwierdzono jednoli-

Tabela 2

Wartość i struktura produkcji [zł/gospodarstwo] według wysokości dopłat bezpośrednich

\begin{tabular}{|c|c|c|c|c|c|c|c|c|c|c|}
\hline \multirow{3}{*}{$\begin{array}{l}\text { Wyszczególnie- } \\
\text { nie }\end{array}$} & \multicolumn{8}{|c|}{ Lata } & \multirow{2}{*}{\multicolumn{2}{|c|}{$\begin{array}{c}\text { Zmiana } \\
\text { 2008/2005 }\end{array}$}} \\
\hline & \multicolumn{2}{|c|}{2005} & \multicolumn{2}{|c|}{2006} & \multicolumn{2}{|c|}{2007} & \multicolumn{2}{|c|}{2008} & & \\
\hline & tys. zł & $\%$ & tys. zł & $\%$ & tys. zł & $\%$ & tys. zł & $\%$ & tys. zł & $\%$ \\
\hline \multicolumn{11}{|c|}{ Grupa I } \\
\hline $\begin{array}{l}\text { Produkcja } \\
\text { roślinna }\end{array}$ & 42,0 & 47,4 & 51,3 & 49,4 & 52,3 & 37,7 & 50,7 & 42,8 & 8,7 & 120,7 \\
\hline $\begin{array}{l}\text { Produkcja } \\
\text { zwierzęca } \\
\end{array}$ & 46,3 & 52,3 & 52,1 & 50,2 & 85,6 & 61,8 & 66,7 & 56,4 & 20,4 & 144,1 \\
\hline $\begin{array}{l}\text { Pozostała } \\
\text { produkcja }\end{array}$ & 0,3 & 0,3 & 0,5 & 0,4 & 0,7 & 0,5 & 0,9 & 0,8 & 0,6 & 300,0 \\
\hline $\begin{array}{l}\text { Ogółem wartość } \\
\text { produkcji gospo- } \\
\text { darstwa rolnego }\end{array}$ & 88,6 & 100,0 & 103,9 & 100,0 & 138,6 & 100,0 & 118,3 & 100,0 & 29,7 & 133,5 \\
\hline \multicolumn{11}{|c|}{ Grupa II } \\
\hline $\begin{array}{l}\text { Produkcja } \\
\text { roślinna }\end{array}$ & 46,9 & 49,4 & 61,0 & 44,7 & 59,4 & 50,8 & 63,7 & 45,5 & 16,8 & 135,8 \\
\hline $\begin{array}{l}\text { Produkcja } \\
\text { zwierzęca } \\
\end{array}$ & 47,1 & 49,7 & 73,7 & 53,9 & 55,6 & 47,5 & 71,9 & 51,4 & 24,8 & 152,7 \\
\hline $\begin{array}{l}\text { Pozostała } \\
\text { produkcja }\end{array}$ & 0,8 & 0,9 & 2,0 & 1,4 & 2,0 & 1,7 & 4,3 & 3,1 & 3,5 & 537,5 \\
\hline $\begin{array}{l}\text { Ogółem wartość } \\
\text { produkcji gospo- } \\
\text { darstwa rolnego }\end{array}$ & 94,8 & 100,0 & 136,7 & 100,0 & 117,0 & 100,0 & 139,9 & 100,0 & 45,1 & 147,6 \\
\hline \multicolumn{11}{|c|}{ Grupa III } \\
\hline $\begin{array}{l}\text { Produkcja } \\
\text { roślinna }\end{array}$ & 106,1 & 46,1 & 112,5 & 43,3 & 168,9 & 58,6 & 173,5 & 60,7 & 67,4 & 163,5 \\
\hline $\begin{array}{l}\text { Produkcja } \\
\text { zwierzęca } \\
\end{array}$ & 121,3 & 52,6 & 142,5 & 54,9 & 115,3 & 40,1 & 106,4 & 37,3 & $-14,9$ & 87,7 \\
\hline $\begin{array}{l}\text { Pozostała } \\
\text { produkcja }\end{array}$ & 3,0 & 1,3 & 4,6 & 1,8 & 3,8 & 1,3 & 5,6 & 2,0 & 2,6 & 186,7 \\
\hline $\begin{array}{l}\text { Ogółem wartość } \\
\text { produkcji gospo- } \\
\text { darstwa rolnego }\end{array}$ & 230,4 & 100,0 & 259,6 & 100,0 & 288,0 & 100,0 & 285,5 & 100,0 & 55,1 & 123,9 \\
\hline
\end{tabular}

Źródło: Opracowanie własne na podstawie danych FADN. 
tej tendencji rosnącej. W 2007 roku produkcja spadła do 117 tys. zł, a w 2008 roku zwiększyła się o 19,5\%, co w porównaniu do 2005 roku oznaczało wzrost o 47,6\%. W grupie gospodarstw o najmniejszych dopłatach w latach 2005-2007 następował systematyczny przyrost wartości produkcji (do 138,6 tys. zł w 2007 roku, tj. o 56,4\%), a następnie spadek w 2008 roku (do 118,3 tys. zł). We wszystkich grupach gospodarstw w badanym okresie struktura produkcji ulegała zmianom w zależności od wysokości dopłat bezpośrednich. W gospodarstwach o największych dopłatach stwierdzono jednolitą tendencję rosnącą wartości produkcji roślinnej w całym badanym okresie - do 173,5 tys. zł w 2008 roku, tj. o $63,5 \%$. Dużo mniejsza zmiana wystąpiła w grupie gospodarstw o średnim poziomie dopłat bezpośrednich, w której uzyskano wartość 63,7 tys. zł w 2008 roku, tj. nastapił wzrost w stosunku do 2005 roku o $35,8 \%$. W gospodarstwach o najmniejszych dopłatach wartość produkcji roślinnej systematycznie rosła do 52,3 tys. zł w 2007 roku, po czym w 2008 roku nastapił niewielki spadek do 50,7 tys. zł. Wartości produkcji zwierzęcej w analizowanym okresie wykazywały zróżnicowane tendencje w poszczególnych grupach. W gospodarstwach o największych dopłatach wartość produkcji zwierzęcej w 2008 roku wynosiła 106,4 tys. zł, i był to spadek w porównaniu z 2005 rokiem o 12,3\%. W grupie gospodarstw o średnim poziomie dopłat bezpośrednich w tym samym okresie produkcja zwierzęca natomiast wzrosła (o 52,7\%), a w gospodarstwach o najmniejszych dopłatach było to zwiększenie o $44,1 \%$.

Oddziaływanie płatności bezpośrednich na wartość produkcji w gospodarstwach rolniczych miało duże znaczenie w podejmowaniu przez rolników decyzji dotyczących przyjętych przez nich strategii gospodarowania. Szczególnie istotny na to wpływ miała produkcja roślinna, gdyż pieniądze z dopłat poprzez uprawy na UR kierowane były do tego działu. Wraz ze wzrostem dopłat bezpośrednich do gospodarstw zwiększał się udział produkcji roślinnej w strukturze produkcji ogółem, jednakże tempo tych zmian w poszczególnych latach było zróżnicowane. Można więc założyć, że tam gdzie rolnicy zainwestowali w produkcję roślinna, nie tylko czynnik obszarowy miał wpływ na wartość produkcji, lecz także pieniądze $\mathrm{z}$ dopłat bezpośrednich przyczyniały się do zwiększenia nakładów materiałowych na nasiona, sadzeniaki, nawozy mineralne, środki ochrony roślin. Poprzez te działania zwiększały produkcję roślinną w postaci większych plonów. W grupie gospodarstw o najwyższym poziomie płatności bezpośrednich mogły znajdować się głównie duże gospodarstwa o typie „,uprawy polowe”, i w początkowym okresie funkcjonowania płatności w latach 2005-2006 przeważała w nich produkcja zwierzęca, która stanowiła odpowiednio 52,6 i 54,9\%. Jednakże w tym czasie rolnicy podejmowali już stosowne decyzje o zwiększaniu potencjału produkcji roślinnej, gdyż w 2007 roku stanowiła ona 58,6\% wartości produkcji rolniczej, a w 2008 roku jej udział wzrósł do $60,7 \%$. W grupie gospodarstw o średnich płat- 
nościach również w pierwszych dwóch latach przeważała produkcja zwierzęca, lecz w 2007 roku produkcja roślinna stanowiła $50,8 \%$, obniżając się nieznacznie w 2008 roku do 45,5\%. Należy zaznaczyć, że w skład tej grupy mogły wchodzić głównie gospodarstwa o typach ,zwierzęta wypasowe” i ,mieszane”, w których zaczęła dominować produkcja zwierzęca. W grupie o najmniejszych dopłatach bezpośrednich dominowały gospodarstwa o typie „Zwierzęta ziarnożerne”, a także „Zwierzęta wypasowe" i ,mieszane”, stąd też od początku produkcja zwierzęca stanowiła w tej grupie większość w strukturze produkcji rolniczej, i w 2007 roku miała ona największy udział (61,8\%).

W tabeli 3 przedstawiono wartość i strukturę rodzajową kosztów netto (bez VAT) poniesionych w danym roku obrachunkowym na działalność operacyjną w gospodarstwie. Największe koszty ogółem odnotowano w gospodarstwach z grupy o najwyższym poziomie dopłat bezpośrednich, w których wystapiła $\mathrm{w}$ analizowanym okresie tendencja rosnąca, jednakże $\mathrm{z}$ różnym nasileniem w poszczególnych latach. W 2005 roku koszty wynosiły 195,3 tys. zł i wzrosły w 2008 roku o $22,6 \%$. W grupie gospodarstw o średnim poziomie dopłat bezpośrednich w tym okresie wzrost kosztów ogółem wyniósł $65,4 \%$, z tą różnica, że po początkowym wzroście nastąił ich spadek w 2007 roku. W roku następnym koszty zwiększyły się do 118,9 tys. zł (o 34,8\%). Największy wzrost kosztów dotyczył gospodarstw o najmniejszych dopłatach, z tendencją rosnącą do 112,5 tys. zł w 2008 roku (o 70,2\%).

\section{Tabela 3}

Wartość i struktura kosztów produkcji [zł/gospodarstwo] według wysokości dopłat bezpośrednich

\begin{tabular}{|c|c|c|c|c|c|c|c|c|c|c|}
\hline \multirow{3}{*}{$\begin{array}{l}\text { Wyszczegól- } \\
\text { nienie }\end{array}$} & \multicolumn{8}{|c|}{ Lata } & \multirow{2}{*}{\multicolumn{2}{|c|}{$\begin{array}{c}\text { Zmiana } \\
2008 / 2005\end{array}$}} \\
\hline & \multicolumn{2}{|c|}{2005} & \multicolumn{2}{|c|}{2006} & \multicolumn{2}{|c|}{2007} & \multicolumn{2}{|c|}{2008} & & \\
\hline & $\begin{array}{l}\text { tys. } \\
\text { zł }\end{array}$ & $\%$ & $\begin{array}{l}\text { tys. } \\
\text { zł }\end{array}$ & $\%$ & $\begin{array}{l}\text { tys. } \\
\text { zł }\end{array}$ & $\%$ & $\begin{array}{l}\text { tys. } \\
\text { zł }\end{array}$ & $\%$ & $\begin{array}{l}\text { tys. } \\
\text { zł }\end{array}$ & $\%$ \\
\hline 1 & 2 & 3 & 4 & 5 & 6 & 7 & 8 & 9 & 10 & 11 \\
\hline \multicolumn{11}{|c|}{ Grupa I } \\
\hline $\begin{array}{l}\text { Zużycie pośred- } \\
\text { nie razem, } \\
\text { w tym: }\end{array}$ & 50,8 & 76,8 & 56,8 & 73,7 & 81,7 & 77,3 & 88,1 & 78,3 & 37,3 & 173,4 \\
\hline $\begin{array}{l}\text { koszty bezpo- } \\
\text { średnie razem }\end{array}$ & 38,1 & 57,6 & 41,5 & 53,9 & 64,8 & 61,3 & 67,3 & 59,8 & 29,2 & 176,6 \\
\hline $\begin{array}{l}\text { koszty } \\
\text { ogólnogo- } \\
\text { spodarcze } \\
\text { razem }\end{array}$ & 12,7 & 19,2 & 15,3 & 19,8 & 16,9 & 16,0 & 20,8 & 18,5 & 8,1 & 163,8 \\
\hline Podatki & 0,7 & 1,0 & 0,8 & 1,0 & 1,1 & 1,0 & 1,3 & 1,2 & 0,6 & 185,7 \\
\hline
\end{tabular}


80

Tabela $3 \mathrm{~cd}$.

\begin{tabular}{|c|c|c|c|c|c|c|c|c|c|c|}
\hline 1 & 2 & 3 & 4 & 5 & 6 & 7 & 8 & 9 & 10 & 11 \\
\hline Amortyzacja & 12,1 & 18,4 & 15,6 & 20,3 & 17,8 & 16,9 & 18,9 & 16,8 & 6,8 & 156,2 \\
\hline $\begin{array}{l}\text { Koszty czynni- } \\
\text { ków zewnętrz- } \\
\text { nych razem }\end{array}$ & 2,5 & 3,8 & 3,9 & 5,0 & 5,0 & 4,8 & 4,2 & 3,7 & 1,7 & 168,0 \\
\hline $\begin{array}{l}\text { Ogółem koszty } \\
\text { produkcji }\end{array}$ & 66,1 & 100,0 & 77,1 & 100,0 & 105,6 & 100,0 & 112,5 & 100,0 & 46,4 & 170,2 \\
\hline \multicolumn{11}{|c|}{ Grupa II } \\
\hline $\begin{array}{l}\text { Zużycie pośred- } \\
\text { nie razem, } \\
\text { w tym: }\end{array}$ & 52,1 & 72,4 & 72,8 & 74,7 & 65,5 & 74,2 & 86,9 & 73,1 & 34,8 & 166,8 \\
\hline $\begin{array}{l}\text { koszty bezpo- } \\
\text { średnie razem }\end{array}$ & 36,2 & 50,3 & 52,0 & 53,4 & 48,8 & 55,3 & 61,5 & 51,7 & 25,3 & 169,9 \\
\hline $\begin{array}{l}\text { koszty } \\
\text { ogólnogo- } \\
\text { spodarcze } \\
\text { razem } \\
\end{array}$ & 15,9 & 22,1 & 20,8 & 21,3 & 16,7 & 18,9 & 25,4 & 21,4 & 9,5 & 159,7 \\
\hline Podatki & 1,0 & 1,5 & 1,1 & 1,1 & 1,0 & 1,2 & 1,4 & 1,2 & 0,4 & 140,0 \\
\hline Amortyzacja & 16,7 & 23,1 & 20,4 & 21,0 & 18,4 & 20,8 & 25,8 & 21,6 & 9,1 & 154,5 \\
\hline $\begin{array}{l}\text { Koszty czynni- } \\
\text { ków zewnętrz- } \\
\text { nych razem }\end{array}$ & 2,1 & 3,0 & 3,1 & 3,2 & 3,3 & 3,8 & 4,8 & 4,1 & 2,7 & 228,6 \\
\hline $\begin{array}{l}\text { Ogółem koszty } \\
\text { produkcji }\end{array}$ & 71,9 & 100,0 & 97,4 & 100,0 & 88,2 & 100,0 & 118,9 & 100,0 & 47,0 & 165,4 \\
\hline \multicolumn{11}{|c|}{ Grupa III } \\
\hline $\begin{array}{l}\text { Zużycie pośred- } \\
\text { nie razem, } \\
\text { w tym: }\end{array}$ & 145,5 & 74,5 & 148,6 & 74,9 & 155,3 & 76,2 & 179,0 & 74,7 & 33,5 & 123,0 \\
\hline $\begin{array}{l}\text { koszty bezpo- } \\
\text { średnie razem }\end{array}$ & 110,8 & 56,7 & 111,0 & 56,0 & 115,9 & 56,9 & 129,9 & 54,2 & 19,1 & 117,2 \\
\hline $\begin{array}{l}\text { koszty } \\
\text { ogólnogo- } \\
\text { spodarcze } \\
\text { razem }\end{array}$ & 34,7 & 17,8 & 37,6 & 18,9 & 39,4 & 19,3 & 49,1 & 20,5 & 14,4 & 141,5 \\
\hline Podatki & 2,8 & 1,4 & 2,4 & 1,2 & 2,9 & 1,4 & 4,3 & 1,8 & 1,5 & 153,6 \\
\hline Amortyzacja & 38,0 & 19,5 & 35,2 & 17,7 & 35,4 & 17,3 & 41,4 & 17,3 & 3,4 & 108,9 \\
\hline $\begin{array}{l}\text { Koszty czynni- } \\
\text { ków zewnętrz- } \\
\text { nych razem }\end{array}$ & 9,0 & 4,6 & 12,2 & 6,2 & 10,3 & 5,1 & 14,8 & 6,2 & 5,8 & 164,4 \\
\hline $\begin{array}{l}\text { Ogółem koszty } \\
\text { produkcji }\end{array}$ & 195,3 & 100,0 & 198,4 & 100,0 & 203,9 & 100,0 & 239,5 & 100,0 & 44,2 & 122,6 \\
\hline
\end{tabular}

Źródło: Opracowanie własne na podstawie danych FADN. 
We wszystkich grupach gospodarstw w badanym okresie wartości poszczególnych grup kosztów w strukturze ulegały zmianom w zależności od wysokości dopłat bezpośrednich. Zużycie pośrednie w gospodarstwach o największych dopłatach wykazywało tendencję rosnącą (wzrosło do 179 tys. zł w 2008 r., tj. o $23 \%$ ). Dużo większe zmiany w tym samym okresie wystapiły w grupie gospodarstw o średnim i najniższym poziomie dopłat bezpośrednich, w których zużycie pośrednie wzrosło odpowiednio o 66,8 i 73,4\%. Koszty amortyzacji kształtowały się w poszczególnych grupach nieco odmiennie i w kolejnych latach wykazywały różne wartości. W gospodarstwach o najmniejszych dopłatach w badanym okresie amortyzacja wykazywała jednolitą tendencję rosnącą - do 18,9 tys. zł w 2008 roku, tj. o 56,2\%. Podobny wzrost (o 54,5\%) dotyczył grupy gospodarstw o średnim poziomie płatności bezpośrednich, z ta jednak różnica, że w 2007 roku nastapił spadek amortyzacji. Najmniejsze zmiany wystąiły w gospodarstwach o największych dopłatach, gdyż po spadku w latach 2006-2007 koszty amortyzacji zwiększyły się o 8,9\% w stosunku do 2005 roku. Taka sytuacja może odzwierciedlać prowadzenie inwestycji przez właścicieli gospodarstw, jednakże o zróżnicowanym tempie, wielkościach i charakterze. W gospodarstwach o najniższym poziomie dopłat bezpośrednich wartość inwestycji była relatywnie mniejsza, lecz wykazywała tendencję rosnącą wraz ze zwiększającymi się środkami finansowymi z tytułu dopłat obszarowych. Przeważnie były to inwestycje na mniejszą skalę, niemające charakteru prorozwojowego, głównie dotyczące zakupów sprzętu oraz maszyn rolniczych. $Z$ tego powodu wartość odpisów amortyzacyjnych w tych gospodarstwach była stosunkowo najmniejsza. W grupie gospodarstw średnich wartość inwestycji była większa niż w tych o najmniejszych dopłatach, z tendencją rosnącą w latach 2005-2006, niewielkim spadkiem w 2007 roku oraz wzrostem w 2008 roku. Właściciele gospodarstw o najwyższym poziomie płatności bezpośrednich prowadzili z kolei stosunkowo duże inwestycje na względnie ustabilizowanym poziomie, a relatywnie większe środki finansowe z tytułu dopłat obszarowych pozwalały rolnikom na większe i bardziej równomierne tempo prac inwestycyjnych.

Koszty czynników zewnętrznych nie stanowiły dużych udziałów w kosztach ogółem, a największy ich przyrost wystąpił w gospodarstwach o średnich dopłatach - z 2,1 tys. zł w 2005 roku wzrosły do 4,8 tys. zł w 2008 roku, tj. o 128,6\%. $\mathrm{W}$ gospodarstwach o najniższym i najwyższym poziomie dopłat bezpośrednich zmiany były mniejsze, a ich zwiększenie w analizowanym okresie wynosiło odpowiednio 68 i 64,4\%. Kwoty podatków były najmniejsze w gospodarstwach o najmniejszych dopłatach i kształtowały się w granicach $0,7-1,3$ tys. zł, a największe występowały w gospodarstwach o najwyższym poziomie płatności - do 4,3 tys. zł w 2008 roku. 
W działalności operacyjnej gospodarstwa rolniczego bardzo ważny jest udział w strukturze poszczególnych kategorii kosztów i relacje, jakie zachodzą między nimi w danym roku obrachunkowym. W grupie gospodarstw o najwyższym poziomie dopłat bezpośrednich w badanym okresie zużycie pośrednie utrzymywało się na stabilnym poziomie, a udział w strukturze kosztów zawierał się od 74,5\% w 2005 roku do 76,2\% w 2007 roku. Zbliżony udział odnotowano $\mathrm{w}$ gospodarstwach o średnim poziomie płatności (do 74,7\% w $2006 \mathrm{r}$.). Nieznacznie pod tym względem odbiegały gospodarstwa o najmniejszych płatnościach, w których zużycie pośrednie kształtowało się w przedziale 76,8$-78,3 \%$. Koszty bezpośrednie w każdej grupie gospodarstw stanowiły ponad 50\% w strukturze wszystkich kosztów (tab. 3). Poziom kosztów ogólnogospodarczych w gospodarstwach o najmniejszych i średnich dopłatach był zbliżony, zawierał się w przedziale 12,7-25,4 tys. zł, a w grupie o największych płatnościach koszty te wynosiły 34,7-49,1 tys. zł. Udział kosztów bezpośrednich w porównaniu z kosztami ogólnogospodarczymi w zużyciu pośrednim we wszystkich prawie grupach wynosił ponad $70 \%$, a największy był w gospodarstwach o najniższym poziomie dopłat bezpośrednich (do 79,3\% w 2007 roku). Potwierdza to fakt, że w skład tej grupy wchodzi dużo gospodarstw o typie „zwierzęta ziarnożerne”, których mniejszy areał nie uprawnia do pobierania dużych dopłat, a w których koszty bezpośrednie w strukturze kosztów ogółem są największe z wszystkich typów gospodarstw, głównie ze względu na udział pasz z zakupu w żywieniu tych zwierząt [Wyniki standardowe... 2010, s. 7-26]. Z kolei w grupie o największych i średnich dopłatach mniejsze koszty bezpośrednie wynikają z przewagi gospodarstw o typach „,uprawy polowe” i ,zwierzęta wypasowe”, w których koszty nawozów, środków ochrony roślin, nasion i pasz dla zwierząt ,"wypasowych” były mniejsze niż w gospodarstwach zwierząt „ziarnożernych”. Należy podkreślić fakt, że udział kosztów bezpośrednich w porównaniu z kosztami ogólnogospodarczymi (w strukturze zużycia pośredniego) w grupie gospodarstw o najwyższym poziomie płatności wykazywał jednolitą tendencję spadkową w badanym okresie - do 72,6\% w 2008 roku.

Największe koszty amortyzacji w strukturze kosztów ogółem wystąpiły w gospodarstwach o średnim poziomie dopłat bezpośrednich, których udział w 2005 roku wynosił 23,1\%, zmniejszając się nieznacznie w 2008 roku do $21,6 \%$. W gospodarstwach o największych dopłatach koszty amortyzacji były najmniejsze, $\mathrm{z}$ jednolitą tendencją malejącą ich udziału w strukturze kosztów ogółem (do 17,3\% w 2008 roku). W gospodarstwach o najmniejszych dopłatach w 2005 roku udział kosztów amortyzacji wynosił 18,4\%, wzrastając w 2006 roku do 20,3\%, a następnie koszty te systematycznie zmniejszały się, osiągając w 2008 roku udział na poziomie 16,8\%. Największy udział kosztów czynników zewnętrznych w strukturze kosztów ogółem występował w gospo- 
darstwach o najwyższym poziomie dopłat bezpośrednich. Około 90\% składników kosztów czynników zewnętrznych to koszty wynagrodzeń za pracę najemną [Wyniki standardowe... 2010, s. 19]. W gospodarstwach największych udział tych kosztów kształtował się w analizowanym okresie od 4,6\% w 2005 roku do $6,2 \%$ w 2008 roku. Mniejszy udział kosztów czynników zewnętrznych występował w gospodarstwach najmniejszych i średnich - do 5\% w 2006 roku. Udział podatków w strukturze kosztów ogółem był największy w gospodarstwach o najwyższym poziomie dopłat bezpośrednich $(1,2-1,8 \%)$, a najmniejszy w grupie o najmniejszych płatnościach $(1,0-1,2 \%)$.

Reasumując, należy podkreślić różnice w wysokości kosztów ogółem, jakie wystapiły w latach 2007-2008 w badanych gospodarstwach, i odnieść je do wartości produkcji ogółem. W 2008 roku w grupie o najwyższym poziomie dopłat bezpośrednich koszty wzrosły o $17,5 \%$, a produkcja spadła o $0,9 \%$, w grupie o średnich dopłatach wzrost kosztów był jeszcze większy i wyniósł 34,8\%, przy jednoczesnym wzroście produkcji o $19,5 \%$. W grupie gospodarstw o najmniejszych dopłatach wzrost kosztów był najmniejszy (o 6,5\%), lecz produkcja w tym samym czasie spadła w tej grupie o $14,7 \%$. W badaniach potwierdzają się wyniki analiz i obliczeń Kowalskiego [2009, s. 82-92] dotyczące dochodów z gospodarstw rolnych według danych Polskiego FADN, które informują o zmniejszeniu realnej wartości dodanej i dochodu $\mathrm{z}$ rodzinnego gospodarstwa rolnego w 2008 roku w stosunku do 2007 roku. Było to wynikiem zwiększenia wartości zużycia pośredniego o $11,2 \%$, podczas gdy wartość produkcji zwiększyła się o $2 \%$. Kowalski [2010, s. 41-44] oraz Dynowska i Łapińska [2010, s. 67-71] podaja, że wskaźnik relacji cen (nożyce cen) produktów rolnych sprzedawanych do towarów i usług zakupywanych na cele bieżącej produkcji rolniczej i inwestycji wynosił w 2008 roku $90,1 \% 5$, a w 2007 roku było to $107,2 \%$. Z tego powodu najbardziej niekorzystnym dla rolnictwa był 2008 rok, gdyż równocześnie koszty bezpośrednie wzrosły o 9,3\%, a koszty ogólnogospodarcze o 12,4\%. Koszty działalności gospodarczej łącznie wzrosły również o tyle samo. Z uwagi na zmniejszenie wartości produkcji i znaczne zwiększenie kosztów ich uzyskania, wszystkie kategorie dochodowe $\mathrm{w}$ analizowanych grupach gospodarstw były relatywnie mniejsze w 2008 roku w porównaniu do tych z lat 2005-2007.

W tabeli 4 przedstawiono wartość dodaną brutto analizowanych gospodarstw w latach 2005-2008 oraz wyniki efektywności jej wykorzystania w rela-

\footnotetext{
${ }^{5}$ Wskaźnik nożyc cen w 2008 roku zmalał przede wszystkim pod wpływem dynamicznego wzrostu cen środków produkcji, któremu towarzyszyły obniżki cen podstawowych produktów rolniczych, w tym głównie zbóż i mleka. Zdecydowane podwyżki cen energii, surowców i nawozów mineralnych na światowych rynkach skutkowały w 2008 roku wzrostem cen detalicznych nawozów mineralnych o ponad $38 \%$, podwyżkami cen środków ochrony roślin o $10 \%$ oraz wzrostem cen energii o 5\% [Kowalski 2010, s. 121-127].
} 
Tabela 4

Wartość dodana brutto [zł]

\begin{tabular}{|c|c|c|c|c|c|c|}
\hline \multirow{3}{*}{ Wyszczególnienie } & \multicolumn{4}{|c|}{ Lata } & \multirow{2}{*}{\multicolumn{2}{|c|}{$\begin{array}{c}\text { Zmiana } \\
2008 / 2005\end{array}$}} \\
\hline & \multirow{2}{*}{2005} & \multirow{2}{*}{2006} & \multirow{2}{*}{2007} & \multirow{2}{*}{2008} & & \\
\hline & & & & & Zł & $\%$ \\
\hline $\begin{array}{l}\text { Wartość dodana brutto/ } \\
\text { /gospodarstwo }\end{array}$ & 78063,5 & 90063,3 & 96346,4 & 87826,7 & 9763,2 & 112,5 \\
\hline $\begin{array}{l}\text { Wartość dodana brutto } \\
\text { na } 1 \text { ha UR }\end{array}$ & 2516,6 & 3148,0 & 3184,0 & 2428,8 & $-87,8$ & 96,5 \\
\hline $\begin{array}{l}\text { Wartość dodana brutto na } \\
1 \text { osobę pełnozatrudnioną }\end{array}$ & 38079,7 & 44807,6 & 49408,4 & 44582,1 & 6502,4 & 117,1 \\
\hline $\begin{array}{l}\text { Wartość dodana brutto na } \\
1 \mathrm{~h} \text { pracy }\end{array}$ & 17,3 & 20,4 & 22,4 & 20,2 & 2,9 & 116,8 \\
\hline
\end{tabular}

Źródło: Opracowanie własne na podstawie danych FADN.

cji do jednostki powierzchni UR (1 ha), na osobę pełnozatrudnioną i $1 \mathrm{~h}$ pracy. W latach 2005-2007 wartość dodana brutto wykazywała tendencję rosnącą do $96346,4 \mathrm{zł}$ w 2007 roku, tj. zwiększyła się o 23,4\%, a w 2008 roku nastąpił jej spadek (o 8,8\% w stosunku do 2007 r.). Zasadniczą tego przyczyną było zwiększenie wartości zużycia pośredniego w 2008 roku w stosunku do 2007 roku, wobec niewielkiego wzrostu produkcji rolniczej ogółem.

W rezultacie szybciej rosnących cen materiałów do produkcji niż produktów rolnych nadwyżka wartości produkcji nad zużyciem pośrednim zmniejszyła się w tym okresie o $16,8 \%$. Taka sytuacja ukierunkowała również podobne tendencje $\mathrm{w}$ relacji wartości dodanej brutto do jednostki powierzchni ziemi i zasobów pracy. W 2005 roku wartość dodana brutto wynosiła 2516,6 zt/ha UR, osiagając w latach 2006-2007 wielkości w granicach 3148-3184 zł/ha UR, obniżając się w 2008 roku do $2428,8 \mathrm{zz} / \mathrm{ha}$ UR. Jedna osoba pełnozatrudniona w gospodarstwie mogła uzyskać w 2005 roku 38 079,7 zł, a w 2007 roku było to już 49 408,4 zł. Oznacza to, że w ciaggu trzech lat nastąpił wzrost wartości dodanej brutto w przeliczeniu na osobę pełnozatrudnioną o $29,7 \%$. Zasadniczą przyczyną tego zjawiska było to, że od 2005 roku wartość dodana brutto na jedno gospodarstwo rosła, i w 2007 roku była największa, a nakłady pracy w tym samym czasie spadały (w 2007 roku były najmniejsze). Takie same relacje wystapiły w przeliczeniu na jednostkę czasu pracy. W 2005 roku na $1 \mathrm{~h}$ pracy przypadało 17,3 zł wartości dodanej brutto, a w 2007 roku było to 22,4 zł. W porównaniu do 2005 roku wartość dodana brutto na $1 \mathrm{~h}$ pracy wzrosła w 2008 roku o 16,8\% i wyniosła $20,2 \mathrm{zł}$.

Średni dochód uzyskiwany w 2005 roku w badanych gospodarstwach rolnych wynosił 40 953,2 zł (tab. 5). W 2006 roku został zwiększony przez rolników do 56969,9 zł, tj. o 39,1\%, a w 2007 roku dochód, jaki uzyskali, był największy w całym analizowanym okresie i wynosił 62365,5 zł. Oznaczało to, że w latach 
Tabela 5

Dochód z rodzinnego gospodarstwa rolniczego [zł]

\begin{tabular}{|c|c|c|c|c|c|c|}
\hline \multirow{3}{*}{ Wyszczególnienie } & \multicolumn{4}{|c|}{ Lata } & \multirow{2}{*}{\multicolumn{2}{|c|}{$\begin{array}{c}\text { Zmiana } \\
2008 / 2005\end{array}$}} \\
\hline & \multirow{2}{*}{2005} & \multirow{2}{*}{2006} & \multirow{2}{*}{2007} & \multirow{2}{*}{2008} & & \\
\hline & & & & & $z \nmid$ & $\%$ \\
\hline Dochód na gospodarstwo & 40953,2 & 56969,9 & 62365,5 & 47225,8 & 6272,6 & 115,3 \\
\hline Dochód na 1 ha UR & 1320,2 & 1991,3 & 2061,0 & 1306,0 & $-14,2$ & 98,9 \\
\hline $\begin{array}{l}\text { Dochód na } 1 \text { osobę } \\
\text { pełnozatrudniona }\end{array}$ & 19977,2 & 28343,2 & 31982,3 & 23972,5 & 3995,3 & 120,0 \\
\hline Dochód na $1 \mathrm{~h}$ pracy & 9,1 & 12,9 & 14,5 & 10,9 & 1,8 & 119,8 \\
\hline
\end{tabular}

Źródło: Opracowanie własne na podstawie danych FADN.

2005-2007 z każdym kolejnym rokiem produkcja rolnicza stawała się coraz bardziej opłacalna, a dochód w tym okresie wzrósł o 53\%. Dopiero w 2008 r. nastąpił spadek dochodu do 47 225,8 zł, czyli w porównaniu z 2007 rokiem zmniejszył się o $24,3 \%{ }^{6}$. Taki sposób tworzenia się dochodów z rodzinnego gospodarstwa rolnego w latach 2005-2008 ukształtował podobne tendencje w relacjach dochodu do posiadanych w gospodarstwach zasobów ziemi i pracy.

W 2005 roku dochód wynosił 1320,2 zł/ha UR, po czym w latach 2006-2007 utrzymywał się na poziomie około $2000 \mathrm{zl} / \mathrm{ha}$ UR, a następnie w 2008 roku obniżył się do wartości jeszcze mniejszej niż z 2005 roku, tj. do 1306 zł/ha UR. Dochód na jedną osobę pełnozatrudnioną w gospodarstwie w 2005 roku wynosił 19 977,2 zł, a w 2006 roku był większy o 41,5\%. W 2007 roku osoba pełnozatrudniona $\mathrm{w}$ gospodarstwie uzyskiwała prawie 32 tys. zł i była to największa kwota otrzymanego dochodu w badanym okresie. A więc w porównaniu z 2005 rokiem, osoba pełnozatrudniona w gospodarstwie zarobiła w 2007 roku więcej o 60\%. Przyczyną takich zmian było to, że od 2005 roku dochód na gospodarstwo stale powiększał się i w 2007 roku był największy, a nakłady pracy w tym samym czasie spadały (w 2007 r. były najmniejsze). Podobne relacje wystąpiły w przeliczeniu na jednostkę czasu pracy, gdyż w 2005 roku uzyskiwano 9,1 zł dochodu na $1 \mathrm{~h}$ pracy, a w 2007 roku o 59,3\% więcej, tj. 14,5 zł, w 2008 roku nastąpiła obniżka do 10,9 zł, co w porównaniu z 2005 rokiem i tak stanowiło przyrost o $19,8 \%$.

\footnotetext{
${ }^{6} \mathrm{~W}$ całym zbiorze indywidualnych gospodarstw rolnych znajdujących się w polu obserwacji PL FADN odnotowano w 2008 roku spadek dochodu z rodzinnego gospodarstwa rolnego o 19,6\% w porównaniu do 2007 roku. Również we wszystkich typach rolniczych (poza uprawami trwałymi) nastąpiło obniżenie dochodu, a największy spadek odnotowały gospodarstwa o typie ,,mieszane" (26,6\%) [Goraj 2009, s. 6].
} 


\section{Wnioski}

W opracowaniu określono wielkość zmian w produkcji i kosztach w indywidualnych gospodarstwach rolniczych w zależności od poziomu dopłat bezpośrednich.

$\mathrm{Na}$ podstawie przeprowadzonych badań sformułowano następujące wnioski:

1. Wartość produkcji rolniczej w gospodarstwach zwiększała się wraz ze wzrostem dopłat bezpośrednich w poszczególnych latach badanego okresu.

2. W gospodarstwach największych pod względem obszarowym wraz ze wzrostem dopłat bezpośrednich zwiększał się udział produkcji roślinnej w strukturze produkcji ogółem. W gospodarstwach najmniejszych obszarowo udział produkcji roślinnej na ogół zmniejszał się w kolejnych latach, co mogło wynikać stąd, że w grupie tej dominowały gospodarstwa o typach „,Zwierzęta ziarnożerne" i ,mieszane”.

3. Dopłaty bezpośrednie były ważnym czynnikiem przyczyniającym się do wprowadzania zmian w zakresie struktury produkcji gospodarstw indywidualnych, a ich oddziaływanie na wartość produkcji miało duże znaczenie w podejmowaniu przez rolników decyzji dotyczących przyjętych przez nich strategii gospodarowania. Szczególnie istotny na to wpływ miała produkcja roślinna, gdyż pieniądze z dopłat poprzez uprawy na UR kierowane były do tego działu.

4. Największe koszty ogółem występowały w gospodarstwach największych pod względem obszarowym, a największe tempo wzrostu kosztów wystapiło w gospodarstwach o najmniejszych dopłatach. Zarówno wartość dodana brutto, jak i dochód $w$ analizowanych grupach gospodarstw były relatywnie małe w 2008 roku od tych z lat 2005-2007, z uwagi na zmniejszenie wartości produkcji i znaczne zwiększenie kosztów. W tych niekorzystnych dla produkcji rolniczej relacjach rynkowych dopłaty bezpośrednie odgrywały ważną rolę w tworzeniu dochodów gospodarstw rolnych.

\section{Literatura}

BERKUM S., TURNER M., 2010: Impacts of direct payments in new member states, candidate countries and potential candidate countries synthesis report, [w:] Agripolicy Enlargement Network for Agripolicy Analysis, 4-16.

CZYŻEWSKI A., 2007: Uniwersalia polityki rolnej w gospodarce rynkowej. Ujęcie makroi mikroekonomiczne, Wydawnictwo Akademii Ekonomicznej, Poznań. 
DAVIDOVA S., 2011: Implementation of Single Area Payment Scheme in the UE New Members States, [w:] A. Sorrentino, R. Henke, S. Severini (red.), The Common Agricultural Policy after the Fischler Reform: National Implementations, Impact Assessment and the Agenda for Future Reforms, Ashgate Publishing Company.

The development and future of the CAP-Reflections paper of the Commission, Commission of the European Communities, com (91) 100 final, Brussels 1991.

DYNOWSKA J., ŁAPIŃSKA A., 2010: Koszty $i$ dochodowość rolniczych gospodarstw towarowych, Roczniki Naukowe SERiA 12, 3, 67-71.

GORAJ L., 2009: Szacunek dochodów gospodarstw rolnych w 2008 r. wedlug parametrów rachunków makroekonomicznych dla rolnictwa z 31.01.2009 r., IERiGŻ-PIB, Warszawa.

JASIŃSKA E., 2008: Indywidualne gospodarstwa rolne $w$ świetle danych rachunkowych z lat 1952-2001, IERiGŻ-PIB, Warszawa.

JUDZIŃSKA A., ŁOPACIUK W., 2011: Wplyw Wspólnej Polityki Rolnej na rolnictwo. Raport Programu Wieloletniego 2011-2014, Raport 9, IERiGŻ-PIB, Warszawa.

KEENEY M., MATTHEWS A., FRAWLEY J., 1997: The distribution of direct payments in Irish agriculture, Dublin Economics Workshop Conference, Kenmare.

KLEPACKI B., 1997: Produkcyjne i ekonomiczne przystosowania gospodarstw prywatnych do zmian warunków gospodarowania, Wydawnictwo SGGW, Warszawa.

KOMOROWSKA D., 2014: Prawidłowości rozwoju rolnictwa a rozwój wspótczesnego rolnictwa, Problemy Rolnictwa Światowego 14 (29), 3, 98-110.

KOWALSKI A. (red.), 2009: Analiza produkcyjno-ekonomicznej sytuacji rolnictwa i gospodarski żywnościowej w 2008 roku, IERiGŻ-PIB, Warszawa.

KOWALSKI A. (red.), 2010: Analiza produkcyjno-ekonomicznej sytuacji rolnictwa i gospodarski żywnościowej w 2009 roku, IERiGŻ-PIB, Warszawa.

KOWALSKI A., 2013: Perspektywy rozwoju rolnictwa europejskiego, [w:] Znaczenie rolnictwa-perspektywa historyczna i międzynarodowa, IERiGŻ-PIB, Warszawa.

KOWALSKI A., REMBISZ W., 2005: Rynek rolny i interwencjonizm a efektywność i sprawiedliwość społeczna, IERiGŻ-PIB, Warszawa.

KUTKOWSKA B., 2009: Wspieranie dochodów rolniczych przez dopłaty bezpośrednie w gospodarstwach Dolnego Ślaska, Journal of Agribusiness and Rural Development 2 (12), 101-109.

MARCYSIAK A., MARCYSIAK A., 2010: Wpływ płatności bezpośrednich na dochody gospodarstwa rolniczego, Roczniki Naukowe SERiA 12, 3, 253-256.

REMBISZ W., BEZAT-JARZĘBOWSKA A., 2013: Ekonomiczny mechanizm ksztattowania dochodów producentów rolnych, IERiGŻ-PIB, Warszawa.

SZPOJANOWSKA J., 2006: Analiza wpływu dopłat bezpośrednich na wyniki produkcyjno-ekonomiczne polskiego rolnictwa, Roczniki Naukowe SERiA 8, 4, 332-336.

Ustawa z 18 grudnia 2003 r. o płatnościach bezpośrednich do gruntów rolnych (Dz.U. 2004 nr 6, poz. 40).

Ustawa z 26 stycznia 2007 r. o płatnościach do gruntów rolnych i platności cukrowej (Dz.U. $2007 \mathrm{nr} 35$, poz. 217).

Ustawa z 29 listopada 2000 r.o zbieraniu i wykorzystywaniu danych rachunkowych z gospodarstw rolnych (Dz.U. $2001 \mathrm{nr} 3$, poz. 20). 
Ustawa o zmianie ustawy o płatnościach do gruntów rolnych i płatności cukrowej oraz ustawy o opłacie skarbowej z dnia 29 lutego 2008 r. (tekst jednolity Dz.U. 2008 nr 170, poz. 1051).

WOŚ A., 2000: Tworzenie i podziat dochodów rolniczych. Dochody transferowe, IERiGŻ-PIB, Warszawa.

Wyniki standardowe uzyskane przez indywidualne gospodarstwa rolne uczestniczace w Polskim FADN w 2008 roku, część II, IERiGŻ-PIB, Warszawa 2010.

ZEGAR J.S., 2008: Dochody w rolnictwie w okresie transformacji i integracji europejskiej, IERiGŻ-PIB, Warszawa.

ŻMIJA D., 2011: System płatności bezpośrednich w Polsce w kontekście rozwiazań stosowanych w Unii Europejskiej, Problemy Rolnictwa Światowego 11, 1 (26).

\section{Abstrakt}

W opracowaniu określono wpływ dopłat bezpośrednich na produkcję, koszty i dochodowość działalności w gospodarstwach rolniczych. Badaniami objęto indywidualne gospodarstwa rolne z terenu województwa śląskiego, uczestniczące w systemie PL-FADN. Okres badawczy obejmował lata 2005-2008. Przeprowadzone badania wykazały, że największe wartości produkcji ogółem uzyskiwały gospodarstwa z grupy o najwyższym poziomie dopłat bezpośrednich. W gospodarstwach największych pod względem obszarowym wraz ze wzrostem dopłat bezpośrednich zwiększał się udział produkcji roślinnej w strukturze produkcji ogółem. Dopłaty bezpośrednie przyczyniały się do wprowadzania zmian w zakresie kierunku i struktury produkcji gospodarstw indywidualnych, a w okresach o niekorzystnej koniunkturze dla produkcji rolniczej stabilizowały dochody gospodarstw rolnych.

Słowa kluczowe: dopłaty bezpośrednie, produkcja rolnicza, koszty, gospodarstwa rolne

\section{The level of direct payments versus production, costs and profitability of individual farms}

\section{Abstract}

The paper aims to determine the impact of direct payments on the production, costs and profitability of individual farms. Our research on individual farms (participating in the EU-FADN) was carried out in Silesian region (for years 2005-2008). Our studies indicated that the highest total production was achieved on farms in the group with the highest level of direct payments. In the group of the 
largest farms (in terms of the area) the share of plant production in the structure of total production increased with then rise of direct payments. Direct payments influenced the changes in the direction and structure of agricultural production in the farms. They also stabilized farm incomes in periods of unfavorable economic conditions for agricultural production.

Key words: direct payments, agricultural production, costs, farms 